\title{
NILAI DAN KONTROL DIRI SEBAGAI FAKTOR PEMBENTUK SIKAP DALAM PERILAKU PEMBELIAN IMPULSIF ANTARGENERASI
}

\author{
M. Ro'is Am ${ }^{* 1}$, Megawati Simanjuntak ${ }^{1}$ \\ ${ }^{1}$ Departemen IImu Keluarga Dan Konsumen, Fakultas Ekologi Manusia, \\ IPB University, Bogor 16680, Indonesia \\ ${ }^{*}$ Email: rois_am@apps.ipb.ac.id
}

\begin{abstract}
Abstrak
Saat ini perkembangan pasar semakin kompleks, namun apabila hal ini tidak diimbangi dengan kemampuan konsumen untuk mengelola pembeliannya dapat menyebabkan munculnya pembelian impulsif. Penelitian ini bertujuan untuk menganalisis pengaruh nilai, kontrol diri, dan sikap terhadap pembelian impulsif generasi Baby Boomer, generasi $\mathrm{X}$, dan generasi $\mathrm{Y}$. Penelitian ini adalah studi kuantitatif dengan menggunakan desain crosssectional study. Pengambilan data dilakukan dengan wawancara menggunakan kuesioner di lima komplek perumahan di Surabaya, Jawa Timur. Responden adalah ibu rumah tangga sebanyak 90 orang yang terbagi dalam tiga generasi yang dipilih dengan menggunakan teknik penarikan contoh non-probability secara quota sampling. Hasil penelitian menunjukkan bahwa pada variabel kontrol diri, sikap, dan pembelian impulsif terdapat perbedaan yang signifikan antargenerasi. Uji pengaruh variabel nilai, kontrol diri, dan sikap terhadap perilaku pembelian impulsif menggunakan metode Stuctural Equation Modelling (SEM). Hasil menunjukkan variabel kontrol diri memengaruhi sikap dan pembelian impulsif secara signifikan. Kontrol diri berpengaruh positif terhadap sikap dan berpengaruh negatif terhadap pembelian impulsif.
\end{abstract}

Kata kunci: generasi berbeda, kontrol diri, nilai, pembelian impulsif, sikap

\section{Value and Self-Control: Determinant Factors of Attitude in Intergenerational Impulsive Buying}

\begin{abstract}
Currently, market developments are become complex, but if this is not balanced with the ability of the consumers to manage their purchases, it can cause impulsive purchases. The purpose of this study was to analyze the influence of values, self-control, and attitudes on impulsive buying behavior of the Baby Boomer generation, generation $\mathrm{X}$, and generation $\mathrm{Y}$. This study applied a quantitative study design and cross-sectional approach, data collection was applied by interviews with questionnaires. The location took place in Surabaya, East Java. This research was conducted in February 2019. Data retrieval applied directly interview on 90 housewife respondents which are divided into three generations, selected by quota sampling. The method which used to assest the influence between variables was Structural Equation Modeling (SEM). The research result found that the variables of self-control, attitude, and impulse buying there were significantly differences. It also found that self-control variables influence attitudes and impulsive buying significantly. Self-control positively influences the attitudes and negatively influences impulsive buying.
\end{abstract}

Keywords: attitude, different generation, impulsive buying, self control, value

\section{PENDAHULUAN}

Saat ini Indonesia memiliki 127 juta penduduk yang bekerja dengan rentang usia antara 1560 tahun lebih (BPS, 2018). Jumlah tersebut terbagi dalam tiga generasi yang berada pada rentang usia yang memiliki perbedaan karakteristik dan keunikannya masing-masing; dan juga sekaligus merupakan kelompok konsumen yang cukup besar dengan karakteristik yang berbeda antargenerasi. Potensi berkembangnya pasar yang kompleks ini dimanfaatkan oleh praktisi, peneliti, dan marketing developer untuk menyesuaikannya dengan kebutuhan, keinginan, dan permintaan konsumen. Menurut Codrington (2008), era seorang individu dilahirkan akan memengaruhi persepsinya mengenai dunia. $\mathrm{Hal}$ ini menyebabkan setiap konsumen memiliki karakteristik yang berbeda-beda dan unik. Williams dan Page (2011) mengembangkan teori generasi dan mengelompokkan individu berdasarkan rentang kelahirannya. Pengelompokan generasi ini dibagi menjadi tiga, yakni generasi baby boomer yang memiliki 
rentang waktu kelahiran antara 1946-1964, generasi $X$ dengan rentang kelahiran antara 1965-1977, dan generasi $Y$ antara 1977-1994 (Williams \& Page, 2011).

Berdasarkan penelitian Livadas (2009), generasi baby boomer yang telah pensiun cenderung memilih pindah dari kota besar ke kota kecil dengan biaya hidup lebih rendah. Baby boomer paling sensitif mengenai harga. Produk dan layanan yang mengatur urusan rumah tangga dan kebutuhan anak-anak menjadi hal yang paling dibutuhkan oleh generasi X. Generasi ini banyak terjebak dalam permasalahan mengenai perumahan (Rosenberg, 2008). Selanjutnya, pada generasi $Y$ atau generasi millennials, lebih dari 90 persen berkomunikasi dengan kelompoknya secara online. Generasi ini merasa cocok dengan teman-temannya sehingga jejaring sosial menjadi satu hal yang penting. Kata kunci untuk generasi ini adalah kolaborasi, keterhubungan, dan kontrol, mayoritas dengan teman sebayanya (Dickey \& Sullivan, 2007; Donnelly, 2008; Read, 2007). Generasi Y dalam penelitian Ezell (2009) menghabiskan lebih dari 150 miliar dollar setiap tahunnya yang digunakan untuk konsumsi barang tambahan seperti mobil, liburan, dan mobile banking. Riset pada generasi yang sama (generasi Y), ditunjukkan oleh Simanjuntak dan Musyifah (2016) yang menyimpulkan bahwa sikap memengaruhi perilaku belanja online. Generasi baby boomer, generasi $\mathrm{Y}$, dan generasi $\mathrm{X}$ didefinisikan dan dijelaskan sesuai dengan karakteristik, gaya hidup, dan sikap setiap generasinya. Bagi pemasar, hal ini perlu untuk menanggapi tren pemasaran dan branding antargenerasi yang disesuaikan dengan bauran pemasaran dan strateginya (Williams \& Page, 2011).

Perilaku pembelian dapat dipengaruhi oleh nilai yang dianut oleh setiap individu, salah satunya adalah nilai hedonisme (Kusmarini, Sumarwan, \& Simanjuntak, 2020; Yistiani, Yasa, \& Suasana, 2012). Setiap individu memiliki struktur nilai yang kompleks, penting, dan berpengaruh dalam pengambilan keputusan konsumen (Yilmaz, Gungordu, dan Yumusak, 2016; Unal \& Ercis, 2006). Selain itu, menurut Paasovaara (2011), nilai dapat menentukan sikap konsumen. Belch dan Belch (2004) dalam bukunya mengatakan bahwa sikap konsumen merupakan suatu hal yang penting bagi pemasar termasuk toko ritel atau bahkan untuk iklan. Iklan dapat mendorong konsumen untuk melakukan pembelian impulsif (Karbasivar \& Yarahmadi, 2011). Menurut Kotler dan Amstrong (2008), perusahaan disarankan untuk menyesuaikan produknya dengan sikap konsumen yang sudah ada daripada mengubahnya. Sikap konsumen berkaitan dengan kontrol atas dirinya. Hurlock (2006) menyebutkan bahwa pengendalian diri individu berhubungan erat dengan emosi serta dorongan yang berasal dari dalam diri sendiri. Peningkatan usia seseorang dapat menyebabkan semakin baiknya kontrol diri dari seorang individu sehingga dapat mengurangi potensinya untuk melakukan pembelian yang impulsif (Budiani \& Larasati, 2014; Ghufron \& Risnawati, 2010). Berbagai permasalahan dan karakteristik yang berbeda akan mendorong perilaku pembelian yang berbeda pula. Selain itu, faktor internal maupun eksternal dapat berpengaruh terhadap perilaku pembelian seorang individu. Nilai menurut Yistiani et al. (2012) yang berpengaruh secara signifikan terhadap pembelian impulsif adalah nilai hedonisme. Sultan, Joireman, dan Sprott (2012) menyebutkan bahwa pembelian impulsif dapat dikurangi dengan adanya kontrol diri. Selain itu, terdapat faktor eksternal seperti diskon atau promo dari sebuah produk yang dapat mendorong sikap konsumen sehingga melakukan pembelian impulsif (Laroche, Pons, Zgolli, Cervellon, \& Kim, 2003). Fokus dari penelitian ini adalah pada analisis dan komparasi pembelian impulsif dari generasi baby boomer, generasi $X$, dan generasi $Y$ yang dipengaruhi oleh nilai, kontrol diri, dan sikap dari setiap generasi yang berbeda. Penelitian ini menjadi menarik dan berbeda dengan penelitian-penelitian sebelumnya karena belum terdapat penelitian yang spesifik membandingkan nilai, kontrol diri, dan sikap terhadap perilaku pembelian konsumen antargenerasi. Seperti penelitian dari Williams dan Page (2011) yang hanya mengklasifikasikan antargenerasi tanpa menjabarkan perbedaan perilaku konsumsi antargenerasinya. Penelitian sebelumnya yang mengkaji perbedaan antar generasi difokuskan pada pembelian kompulsif (Gania \& Simanjuntak, 2019), dan keputusan investasi wanita (Putri \& Simanjuntak, 2020).

Penelitian ini bertujuan untuk mengidentifikasi nilai, kontrol diri, sikap, dan perilaku pembelian impulsif pada keluarga generasi baby boomer, generasi $X$, dan generasi $Y$; menganalisis perbedaan nilai, kontrol diri, sikap, dan perilaku pembelian impulsif pada keluarga generasi baby boomer, generasi $\mathrm{X}$, dan generasi $\mathrm{Y}$; dan menganalisis pengaruh nilai, kontrol diri, dan sikap terhadap perilaku pembelian impulsif pada keluarga generasi baby boomer, generasi $\mathrm{X}$, dan generasi $\mathrm{Y}$. Gambar 1 menunjukkan kerangka pemikiran penelitian. 


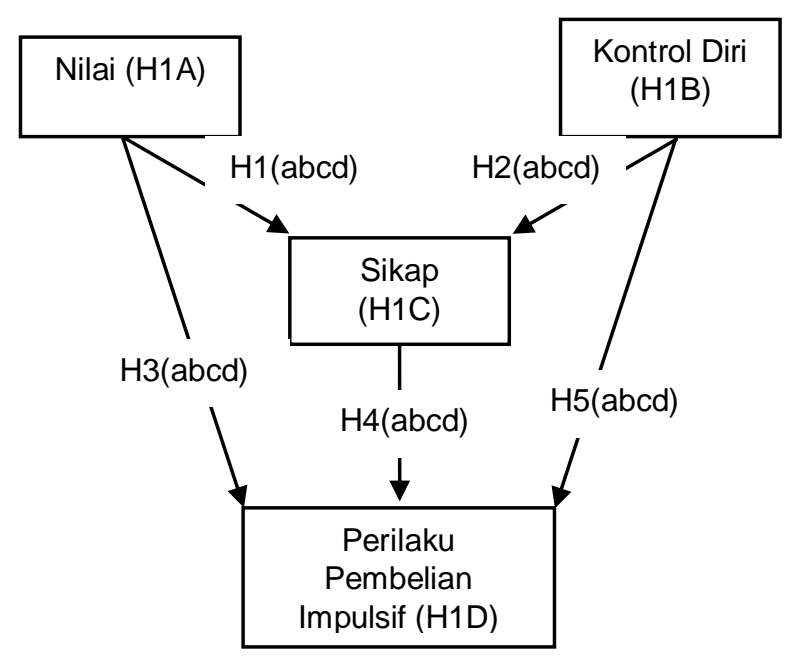

Gambar 1 Kerangka pemikiran penelitian

Berdasarkan kerangka pemikiran pada Gambar 1 , hipotesis yang akan dijawab pada penelitian ini adalah sebagai berikut:

1. H1A : Terdapat perbedaan signifikan nilai antara generasi baby boomer, generasi $X$, dan generasi $Y$

H1B : Terdapat perbedaan signifikan kontrol diri antara generasi baby boomer, generasi $\mathrm{X}$, dan generasi Y

H1C : Terdapat perbedaan signifikan sikap antara generasi baby boomer, generasi $\mathrm{X}$, dan generasi Y

H1D : Terdapat perbedaan signifikan pembelian impulsif antara generasi baby boomer, generasi $\mathrm{X}$, dan generasi $Y$

2. $\mathrm{H} 1 \mathrm{a}$ : Nilai berpengaruh signifikan terhadap sikap pada generasi baby boomer

$\mathrm{H} 1 \mathrm{~b}$ : Nilai berpengaruh signifikan terhadap sikap pada generasi $X$

$\mathrm{H} 1 \mathrm{C}$ : Nilai berpengaruh signifikan terhadap sikap pada generasi $Y$

$\mathrm{H} 1 \mathrm{~d}$ : Nilai berpengaruh signifikan terhadap sikap pada semua generasi

3. $\mathrm{H} 2 \mathrm{a}$ : Kontrol diri berpengaruh signifikan terhadap sikap pada generasi baby boomer

$\mathrm{H} 2 \mathrm{~b}$ : Kontrol diri berpengaruh signifikan terhadap sikap pada generasi $X$

H2C : Kontrol diri berpengaruh signifikan terhadap sikap pada generasi $Y$

$\mathrm{H} 2 \mathrm{~d}$ : Kontrol diri berpengaruh signifikan terhadap sikap pada semua generasi

4. $\mathrm{H} 3 \mathrm{a}$ : Nilai berpengaruh signifikan terhadap pembelian impulsif pada generasi baby boomer
$\mathrm{H} 3 \mathrm{~b}$ : Nilai berpengaruh signifikan terhadap pembelian impulsif pada generasi $X$

$\mathrm{H} 3 \mathrm{c}$ : Nilai berpengaruh signifikan terhadap pembelian impulsif pada generasi $Y$

$\mathrm{H} 3 \mathrm{~d}$ : Nilai berpengaruh signifikan terhadap pembelian impulsif pada semua generasi

5. $\mathrm{H} 4 \mathrm{a}$ : Sikap berpengaruh signifikan terhadap pembelian impulsif pada generasi baby boomer

$\mathrm{H} 4 \mathrm{~b}$ : Sikap berpengaruh signifikan terhadap pembelian impulsif pada generasi $X$

$\mathrm{H} 4 \mathrm{c}$ : Sikap berpengaruh signifikan terhadap pembelian impulsif pada generasi $Y$

$\mathrm{H} 4 \mathrm{~d}$ : Sikap berpengaruh signifikan terhadap pembelian impulsif pada semua generasi

6. H5a : Kontrol diri berpengaruh signifikan terhadap pembelian impulsif pada generasi baby boomer

$\mathrm{H} 5 \mathrm{~b}$ : Kontrol diri berpengaruh signifikan terhadap pembelian impulsif pada generasi $X$

$\mathrm{H} 5 \mathrm{C}$ : Kontrol diri berpengaruh signifikan terhadap pembelian impulsif pada generasi $Y$

$\mathrm{H} 5 \mathrm{~d}$ : Kontrol diri berpengaruh signifikan terhadap pembelian impulsif pada semua generasi

Penelitian ini menjadi menarik dan berbeda dengan penelitian-penelitian sebelumnya, karena belum terdapat penelitian yang spesifik membandingkan nilai, kontrol diri, dan sikap terhadap perilaku pembelian konsumen lintas generasi. Penelitian sebelumnya yang mengkaji pembelian impulsif pada tiga generasi berbeda dilakukan oleh Pramesty dan Simanjuntak (2020) dengan variabel yang memengaruhi adalah konsep diri, gaya hidup, strategi pemasaran.

\section{METODE}

Penelitian ini menggunakan desain studi kuantitatif dan cross sectional study. Teknik yang digunakan dalam penelitian ini adalah dengan wawancara secara langsung kepada responden. Pengambilan data dilaksanakan di tiga perumahan di Kota Surabaya, Jawa Timur. Unit analisis dalam penelitian ini adalah keluarga dan respondennya adalah ibu rumah tangga yang lahir pada rentang tahun 19461994 yang terbagi dalam tiga kelompok generasi, yakni generasi baby boomer, generasi $X$, dan generasi $Y$. 
Teknik penarikan contoh dilakukan dengan nonprobability sampling secara quota sampling. Teknik sampling ini diambil karena peneliti ingin mengklasifikasikan populasi dalam beberapa kelompok generasi, setelah kuota dalam kelompok generasi telah terpenuhi maka pengumpulan data dihentikan. Total jumlah responden yang diteliti adalah sebanyak 90 responden yang terbagi dalam tiga generasi dengan masing-masing generasi memiliki kuota sejumlah 30 responden.

Penelitian ini menggunakan sumber data primer. Data primer diperoleh melalui wawancara secara langsung pada responden. Kuesioner digunakan sebagai alat bantu untuk memperoleh data variabel yang diteliti. Data yang diambil meliputi karakteristik responden (tahun kelahiran, usia, pendidikan, pekerjaan, pendapatan, dan pengeluaran keluarga), nilai, kontrol diri, sikap, dan pembelian impulsif.

Nilai menurut Sumarwan (2011) merupakan sebuah kepercayaan tentang suatu hal, bukan hanya soal kepercayaan, akan tetapi nilai adalah hal-hal yang dapat mengarahkan seseorang untuk berperilaku sesuai dengan budayanya. Variabel nilai yang diacu dari Burroughs dan Rindfleisch (2002) pada penelitian ini terdiri atas tiga dimensi yaitu dimensi family values dan value conflict dengan tiga indikator, dan dimensi community value dengan empat indikator.

Kontrol diri didefinisikan Hurlock (2006) sebagai bentuk pengendalian diri individu terhadap emosinya serta dorongan dari dalam dirinya sendiri. Variabel kontrol diri yang diacu dari penelitian Tangney, Boone, dan Baumeister (2018) terdiri atas dua dimensi, yaitu dimensi inhibitory dan dimensi initiatory yang masingmasing memiliki tiga indikator. Dimensi inhibitory menjelaskan kemampuan seorang individu untuk mengabaikan dorongan untuk berbuat negatif, sedangkan dimensi initiatory menjelaskan kemampuan individu untuk berbuat yang positif.

Penelitian Gunawan (2015) menyebutkan bahwa sikap dapat memberikan keyakinan yang kuat terhadap suatu objek. Hal ini memengaruhi evaluasi konsumen atas perasaan yang menguntungkan dan tidak menguntungkan serta tindakannya untuk membeli sebuah produk. Variabel sikap yang diacu dari Solomon (2017) terdiri atas tiga dimensi yaitu affective dan behavior dengan tiga indikator, dan dimensi cognitive dengan empat indikator.
Herabadi (2003) dalam penelitiannya menemukan bahwa perilaku pembelian impulsif dilakukan secara tidak sengaja dan secara tidak sadar melibatkan berbagai macam motif, serta diikuti dengan respon emosional yang kuat dari dalam diri sendiri. Variabel pembelian impulsif yang diacu dari Verplanken dan Herabadi (2001) terdiri atas dua dimensi, yaitu affective dengan lima indikator dan cognitive dengan empat indikator.

Penelitian ini menggunakan empat skala pengukuran yakni sangat tidak setuju yang diberi nilai satu, tidak setuju dengan nilai dua, setuju dengan nilai tiga, dan sangat setuju dengan nilai empat. Skor yang diperoleh di setiap variabel ditransformasikan dalam bentuk indeks. Selanjutnya, skor indeks dibagi dalam tiga kategori menggunakan cut off (rendah 060 , sedang 60-80, tinggi 80-100).

Data yang berhasil didapatkan sebelumnya kemudian diolah dengan proses editing, coding, input data, cleaning data, dan analisis data. Aplikasi yang digunakan dalam pengolahan dan analisis data menggunakan Microsoft Excel, Statistical Package for Social Science (SPSS), dan Smart PLS. Analisis data dilakukan dengan cara deskriptif untuk melihat sebaran data karakteristik responden serta sebaran jawaban responden. Sementara itu, analisis one way anova digunakan untuk melihat perbedaan variabel pada generasi baby boomer, generasi $X$, dan generasi $Y$. Penelitian ini juga menggunakan uji pengaruh variabel nilai, kontrol diri,dan sikap terhadap perilaku pembelian impulsif menggunakan Structural Equation Modelling (SEM).

\section{HASIL}

\section{Karakteristik Responden}

Pendapatan. Pendapatan erat kaitannya dengan pengeluaran. Pada penelitian ini ditemukan perbedaan yang signifikan pada pendapatan per kapita dan pengeluaran per kapita generasi baby boomer, generasi $X$, dan generasi $Y$. Generasi $Y$ memiliki pendapatan per kapita yang tertinggi dibandingkan dengan dua generasi lainnya, yakni sebesar Rp3.915.277. Hal ini disebabkan karena generasi ini dibandingkan dengan generasi lainnya terkategori pada umur yang masih sangat produktif. Pada pengeluaran per kapita justru generasi $X$ yang tertinggi, yakni sebesar Rp2.624.246. Hal ini terjadi karena mayoritas generasi $X$ memiliki anak pertama remaja dan anak selanjutnya berusia sekolah sehingga 
pengeluaran dalam satu bulannya lebih tinggi dibandingkan dengan generasi lainnya.

Pendidikan. Berdasarkan hasil uji anova ditemukan perbedaan yang siginifikan pada lama pendidikan suami responden lintas generasi. Mayoritas (46,7\%) suami responden pada generasi $Y$ berpendidikan terakhir S1 dan sebanyak seperenam (16,7\%) responden berpendidikan terakhir S2. Mayoritas responden generasi $Y(63,3 \%)$ berpendidikan terakhir S1. Responden generasi $X$ antara suami dan istri memiliki persentase yang sama, yakni 50 persen yang berpendidikan terakhir S1. Sementara itu, pada generasi baby boomer suami dan istri yang berpendidikan terakhir S1 memiliki persentase terendah dibandingkan dengan generasi yang lain karena generasi ini mayoritasnya berpendidikan terakhir SMA.

Pekerjaan. Jenis pekerjaan yang paling banyak ditekuni oleh suami responden generasi $Y$ adalah karyawan swasta. Setelah itu, sebanyak tujuh dari 30 responden pekerjaannya adalah sebagai wiraswasta. Mayoritas istri dari ketiga generasi tidak memiliki pekerjaan atau berperan sebagai ibu rumah tangga, namun generasi $Y$ memiliki persentase yang terendah (33,3\%). Generasi X menempati urutan pertama dengan jumlah ibu rumah tangga terbanyak dibandingkan generasi yang lainnya, yakni sebesar 60 persen. Selain itu, dua dari lima suami generasi baby boomer mayoritasnya berpenghasilan dari uang pensiun bulanan.

\section{Nilai}

Secara umum, responden generasi baby boomer, $\mathrm{X}$, dan $\mathrm{Y}$ memiliki nilai yang terkategori sedang (Tabel 1). Hal ini disebabkan karena ketiga generasi cenderung mengutamakan kepentingan keluarga dibandingkan dengan yang lain. Generasi baby boomer dan generasi $Y$ memiliki family values yang tinggi. Lebih lanjut, kedua generasi ini menganggap bahwa family values adalah suatu hal yang penting. Penelitian ini juga menemukan bahwa terdapat 60 persen generasi baby boomer dan generasi $\mathrm{Y}$ memiliki community values yang sedang dan sebanyak 50 persen responden generasi ini juga terkategori sedang pada dimensi conflict values. Secara keseluruhan, hasil rataan indeks menunjukkan bahwa rataan indeks family values $(81,5)$ tertinggi dibandingkan dimensi community values $(75,6)$ dan conflict values $(59,6)$. Pada uji beda dengan one-way anova, ditemukan bahwa tidak ada perbedaan yang signifikan diantara generasi baby boomer, $\mathrm{X}$, dan $Y$ pada dimensi variabel nilai. Hal ini menunjukkan bahwa nilai-nilai yang ada pada ketiga generasi ini cenderung sama meskipun memiliki perbedaan usia dan siklus keluarga yang telah dilewati. Berdasarkan sebaran jawaban responden dari responden ketiga generasi juga memiliki jawaban yang cenderung sama, yakni setuju dan sangat setuju.

Family Values. Responden generasi baby boomer, generasi $\mathrm{X}$, dan generasi $\mathrm{Y}$ sepakat bahwa keluarga adalah prioritas dan hubungan dalam keluarga itu hal yang paling penting. Responden juga memilih untuk memiliki waktu bersama keluarga dibandingkan dengan lembur kerja. Selain itu, menjaga hubungan dengan tetangga menurut semua responden dari ketiga generasi merupakan hal yang penting.

Tabel 1 Sebaran responden dan rataan indeks berdasarkan kategori dimensi variabel nilai

\begin{tabular}{|c|c|c|c|c|}
\hline Kategori & $\begin{array}{c}\text { Gen } \\
\text { BB }\end{array}$ & Gen X & $\begin{array}{c}\text { Gen } \\
Y\end{array}$ & $\begin{array}{c}\text { Semua } \\
\text { Generasi }\end{array}$ \\
\hline \multicolumn{5}{|c|}{ Family values } \\
\hline Rendah & 10,0 & 3,3 & 6,7 & 6,7 \\
\hline Sedang & 43,3 & 53,3 & 43,3 & 46,7 \\
\hline Tinggi & 46,7 & 43,3 & 50,0 & 46,7 \\
\hline $\begin{array}{l}\text { Rataan } \\
\text { indeks }\end{array}$ & 79,6 & 82,5 & 82,2 & 81,5 \\
\hline$p$-value & \multicolumn{4}{|c|}{0,673} \\
\hline \multicolumn{5}{|c|}{ Community values } \\
\hline Rendah & 3,3 & 13,3 & 10,0 & 8,9 \\
\hline Sedang & 60,0 & 50,0 & 60,0 & 56,7 \\
\hline Tinggi & 36,7 & 36,7 & 30,0 & 34,4 \\
\hline $\begin{array}{l}\text { Rataan } \\
\text { indeks }\end{array}$ & 77,5 & 74,4 & 75,0 & 75,6 \\
\hline$p$-value & \multicolumn{4}{|c|}{0,567} \\
\hline \multicolumn{5}{|c|}{ Conflict values } \\
\hline Rendah & 36,7 & 46,7 & 43,3 & 42,2 \\
\hline Sedang & 50,0 & 50,0 & 53,3 & 51,1 \\
\hline Tinggi & 13,3 & 3,3 & 3,3 & 6,7 \\
\hline $\begin{array}{l}\text { Rataan } \\
\text { indeks }\end{array}$ & 63,7 & 56,6 & 58,5 & 59,6 \\
\hline$p$-value & \multicolumn{4}{|c|}{0,248} \\
\hline \multicolumn{5}{|l|}{ Nilai } \\
\hline Rendah & 26,7 & 6,7 & 6,7 & 13,3 \\
\hline Sedang & 73,3 & 83,3 & 93,3 & 83,3 \\
\hline Tinggi & 0,0 & 10,0 & 0,0 & 3,3 \\
\hline $\begin{array}{l}\text { Rataan } \\
\text { Indeks }\end{array}$ & 74,0 & 71,5 & 72,2 & 72,6 \\
\hline$p$-value & \multicolumn{4}{|c|}{0,513} \\
\hline
\end{tabular}


Community Values. Hasil penelitian menunjukkan bahwa sebanyak tujuh dari sepuluh responden generasi baby boomer menganggap mudah dalam mengambil keputusan dan tidak membutuhkan banyak pertimbangan. Pada generasi $X$ dan generasi $Y$ terdapat 80 persen responden tidak ragu untuk menentukan arah atau tujuan dalam hidup. Generasi X jika dibandingkan dengan dua generasi yang lainnya cenderung memerlukan banyak pertimbangan ketika memilih di antara dua plihan yang ada.

Conflict Values. Hasil penelitian memperlihatkan, generasi baby boomer pada dimensi conflict values menganggap mudah dalam mengambil keputusan dan tidak membutuhkan banyak pertimbangan. Pada generasi $X$ dan generasi $Y$ mayoritas responden tidak ragu untuk menentukan arah atau tujuan dalam hidup. Generasi X jika dibandingkan dengan dua generasi yang lainnya cenderung memerlukan banyak pertimbangan ketika memilih diantara dua plihan yang ada.

\section{Kontrol Diri}

Kontrol diri merupakan bentuk pengendalian diri responden terhadap dorongan dari dalam diri sendiri untuk berbuat spontan dan mungkin dapat merugikannya. Generasi baby boomer memiliki kontrol diri yang tinggi dibandingkan dengan generasi $X$ dan $Y$. Hasil yang tersaji pada Tabel 2 menunjukkan bahwa responden generasi $X(56,6 \%)$ dan $Y(60 \%)$ terkategori rendah dalam dimensi inhibitory.

Hal yang berbeda ditunjukan generasi baby boomer yang tersebar merata sebesar 33,3 persen pada semua kategori. Berdasarkan data ini dapat dikatakan bahwa generasi $X$ dan $Y$ rendah kemampuannya untuk mengabaikan dorongan perilaku negatif dibandingkan dengan generasi baby boomer. Responden semua generasi pada dimensi initiatory sebanyak 45,6 persen berkategori sedang, berbeda halnya dengan generasi $X$ dan $Y$ sebanyak 46,7 persen berkategori rendah.

Uji anova pada dimensi variabel kontrol diri ditemukan adanya perbedaan yang signifikan antara generasi baby boomer dengan generasi $X$ dan $Y$. Perbedaan ini terlihat pada dimensi inhibitory atau yang dikenal dengan kemampuan untuk mengabaikan dorongan perilaku negatif. Secara umum, kontrol diri antara generasi baby boomer dengan generasi $\mathrm{X}$ dan $\mathrm{Y}$ juga berbeda signifikan. Generasi baby boomer berdasarkan pada penelitian ini dinilai lebih mampu untuk mengabaikan dorongan untuk berperilaku negatif. Pada dimensi initiatory tidak ditemukan perbedaan yang signifikan antar ketiga generasi (Tabel 2).

Inhibitory. Responden generasi baby boomer mengaku mudah untuk meninggalkan hal-hal yang dianggap buruk. Generasi $Y$ pada penelitian ini mudah berubah pikiran, sedangkan responden generasi $X$ merasa sulit untuk berkonsentrasi. Hal ini dilatarbelakangi oleh rata-rata usia generasi $Y$ masih tergolong muda dan masih banyak hal yang ingin dilakukan, sedangkan generasi $X$ mulai menemukan permasalahan pada anak usia sekolah serta permasalahan rumah tangga lainnya.

Tabel 2 Sebaran responden dan rataan indeks berdasarkan kategori dimensi variabel kontrol diri

\begin{tabular}{|c|c|c|c|c|}
\hline Kategori & Gen BB & Gen X & Gen Y & Semua Gen \\
\hline \multicolumn{5}{|l|}{ Inhibitory } \\
\hline Rendah & 33,3 & 56,7 & 60,0 & 50,0 \\
\hline Sedang & 33,3 & 36,7 & 30,0 & 33,3 \\
\hline Tinggi & 33,3 & 6,7 & 10,0 & 16,7 \\
\hline $\begin{array}{l}\text { Rataan } \\
\text { indeks }\end{array}$ & $70,0^{a}$ & $57,7^{\mathrm{bc}}$ & $58,5^{\mathrm{cb}}$ & 62,1 \\
\hline$p$-value & \multicolumn{4}{|c|}{$0,014^{\star \star}$} \\
\hline \multicolumn{5}{|l|}{ Initiatory } \\
\hline Rendah & 30,0 & 46,7 & 46,7 & 41,1 \\
\hline Sedang & 53,3 & 43,3 & 40,0 & 45,6 \\
\hline Tinggi & 16,7 & 10,0 & 13,3 & 13,3 \\
\hline $\begin{array}{l}\text { Rataan } \\
\text { indeks }\end{array}$ & 68,1 & 63,3 & 65,9 & 65,8 \\
\hline$p$-value & \multicolumn{4}{|c|}{0,475} \\
\hline \multicolumn{5}{|c|}{ Kontrol Diri } \\
\hline Rendah & 26,7 & 40,0 & 33,3 & 33,3 \\
\hline Sedang & 46,7 & 56,7 & 63,3 & 55,6 \\
\hline Tinggi & 26,7 & 3,3 & 3,3 & 11,1 \\
\hline $\begin{array}{l}\text { Rataan } \\
\text { indeks }\end{array}$ & $69,0^{\mathrm{a}}$ & $60,5^{b c}$ & $62,2^{\mathrm{cb}}$ & 63,9 \\
\hline$p$-value & \multicolumn{4}{|c|}{$0,031^{* *}$} \\
\hline
\end{tabular}

Keterangan: **)signifikan pada $p$ value $<0,05$, huruf superscript yang berbeda menunjukkan adanya perbedaan signifikan antar generasi; ${ }^{a}=$ Generasi baby boomer berbeda signifikan dengan generasi $\mathrm{X}$ dan $\mathrm{Y}$; ${ }^{\mathrm{bc}}=$ Generasi $\mathrm{X}$ berbeda signifikan dengan generasi baby boomer tapi tidak dengan generasi $Y$; ${ }^{\mathrm{cd}}=$ Generasi $\mathrm{Y}$ berbeda signifikan dengan generasi baby boomer tapi tidak dengan generasi $X$ 
Initiatory. Hasil analisis data terkait perbandingan ketiga generasi memperlihatkan bahwa generasi baby boomer dan generasi $Y$ lebih suka untuk menunda pekerjaan dibandingkan dengan generasi $\mathrm{X}$. Lebih lanjut, semua responden Baby boomer mengaku mampu menjaga rahasia dengan baik, dan mayoritas responden generasi $Y$ mengaku mampu bersikap disiplin dalam kehidupan sehari-hari.

\section{Sikap}

Sikap adalah ungkapan perasaan, perilaku, dan pengetahuan responden pada suatu objek. Berdasarkan penelitian ini, responden pada generasi baby boomer, $\mathrm{X}$, dan $\mathrm{Y}$ cenderung memiliki sikap yang netral. Generasi baby boomer $(83,3 \%)$ dan generasi $X \quad(86,7 \%)$ terkategori negatif pada dimensi affective. Sebanyak 70 persen dari responden generasi $Y$ memiliki behavior yang netral dan rata-rata generasi baby boomer dan generasi $\mathrm{X}$ juga terkategori netral.

Generasi baby boomer $(43,3)$ pada dimensi cognitive terkategori negatif, sedangkan generasi $X$ dan $Y$ netral. Pada uji anova terlihat perbedaan signifikan pada dimensi cognitive. Ditemukan juga terdapat perbedaan yang signifikan antara generasi baby boomer dengan generasi $\mathrm{X}$ dan $\mathrm{Y}$. Pada dimensi affective dan behavior tidak terlihat perbedaan yang signifikan di antara ketiga generasi tersebut (Tabel 3).

Affective. Responden generasi $Y$ melakukan pembelian karena dipengaruhi oleh mood atau perasaan, sedangkan semua responden generasi baby boomer membeli karena memang sesuai dengan kebutuhan. Generasi X dibandingkan dengan dua generasi lainnya paling tidak senang membeli produk karena orang lain banyak membelinya juga.

Behavior. Generasi $Y$ pada penelitian ini adalah generasi yang aktif melakukan komplain. Mayoritas responden dari generasi baby boomer, generasi $\mathrm{X}$, dan generasi $\mathrm{Y}$ memilih untuk membeli produk di toko yang suasananya nyaman. Jika mengalami penurunan pendapatan, maka ketiga generasi juga akan mengurangi pembelian.

Cognitive. Mayoritas responden generasi $X$ dan $Y$ yang tidak mudah percaya dengan iklan yang ada di media massa. Responden generasi baby boomer menganggap penting informasi mengenai tempat belanja dan akan memengaruhinya dalam melakukan pembelian, sedangkan responden generasi $Y$ mengatakan bahwa harga yang akan memengaruhi pembelian. Rata-rata responden generasi baby boomer, generasi $\mathrm{X}$, dan generasi menyatakan penting untuk meneliti terlebih dahulu produk kemasan yang akan dibeli.

Tabel 3 Sebaran responden dan rataan indeks berdasarkan kategori dimensi variabel sikap

\begin{tabular}{|c|c|c|c|c|}
\hline Kategori & $\begin{array}{c}\text { Gen } \\
\text { BB }\end{array}$ & $\begin{array}{c}\text { Gen } \\
X\end{array}$ & $\begin{array}{c}\text { Gen } \\
Y\end{array}$ & $\begin{array}{l}\text { Semua } \\
\text { Gen }\end{array}$ \\
\hline \multicolumn{5}{|l|}{ Affective } \\
\hline Negatif & 83,3 & 86,7 & 63,3 & 77,8 \\
\hline Netral & 16,7 & 13,3 & 36,7 & 22,2 \\
\hline Positif & 0,0 & 0,0 & 0,0 & 0,0 \\
\hline $\begin{array}{l}\text { Rataan } \\
\text { indeks }\end{array}$ & 51,1 & 52,2 & 56,7 & 53,3 \\
\hline$p$-value & \multicolumn{4}{|c|}{0,103} \\
\hline \multicolumn{5}{|l|}{ Behavior } \\
\hline Negatif & 26,7 & 23,3 & 6,7 & 18,9 \\
\hline Netral & 46,7 & 50,0 & 70,0 & 55,6 \\
\hline Positif & 26,7 & 26,7 & 23,3 & 25,6 \\
\hline $\begin{array}{l}\text { Rataan } \\
\text { indeks }\end{array}$ & 73,4 & 75,1 & 74,4 & 74,4 \\
\hline$p$-value & \multicolumn{4}{|c|}{0,924} \\
\hline
\end{tabular}

\begin{tabular}{|c|c|c|c|c|}
\hline Cognitive & & & & \\
\hline Negatif & 43,3 & 20,0 & 16,7 & 26,7 \\
\hline Netral & 36,7 & 43,3 & 56,7 & 45,6 \\
\hline Positif & 20,0 & 36,7 & 26,7 & 27,8 \\
\hline $\begin{array}{l}\text { Rataan } \\
\text { indeks }\end{array}$ & $66,1^{a}$ & $\begin{array}{r}74,1^{\mathrm{b}} \\
\mathrm{c}\end{array}$ & $\begin{array}{r}73,6^{c} \\
b\end{array}$ & 71,3 \\
\hline$p$-value & \multicolumn{4}{|c|}{$0,030^{\star *}$} \\
\hline
\end{tabular}

\begin{tabular}{lrrrr}
\hline Sikap & & & & \\
\hline Negatif & 26,7 & 6,7 & 6,7 & 13,3 \\
Netral & 73,3 & 83,3 & 93,3 & 83,3 \\
Positif & 0,0 & 10,0 & 0,0 & 3,3 \\
Rataan & $63,9^{\mathrm{a}}$ & $\begin{array}{r}67,9^{\mathrm{b}} \\
\text { indeks }\end{array}$ & $\begin{array}{c}68,7^{\mathrm{c}} \\
\mathrm{b}\end{array}$ & 66,8 \\
p-value & \multicolumn{4}{c}{$0,058^{*}$} \\
\hline
\end{tabular}

Keterangan: *) signifikan pada $p$ value $\left.<0,1 ;{ }^{* *}\right)$ signifikan pada $p$ value $<0,05$; Huruf superscript yang berbeda menunjukkan adanya perbedaan signifikan antar generasi ${ }^{a}=$ Generasi baby boomer berbeda signifikan dengan generasi $X$ dan $Y ;{ }^{b c}=$ Generasi $X$ berbeda signifikan dengan generasi baby boomer tapi tidak dengan generasi $\mathrm{Y}$; ${ }^{\mathrm{cd}}=$ Generasi $\mathrm{Y}$ berbeda signifikan dengan generasi baby boomer tapi tidak dengan generasi $X$ 


\section{Pembelian Impulsif}

Pembelian impulsif adalah perilaku membeli yang dilakukan secara tidak sadar karena adanya dorongan dari dalam diri sendiri dan dilakukan tanpa perencanaan pembelian sebelumnya. Pada penelitian ini ditemukan bahwa semua responden generasi baby boomer tergolong rendah pembelian impulsifnya.

Hasil penelitian memperlihatkan bahwa secara umum, generasi baby boomer, generasi $\mathrm{X}$, dan generasi $Y$ tergolong rendah pembelian impulsifnya. Selain itu, generasi baby boomer, generasi $X$, dan generasi $Y$ dalam dimensi cognitive dan affective juga terkategori rendah. Pembelian impulsif yang terkategori rendah mengindikasikan bahwa ketiga generasi ini cenderung berbelanja secara terencana dan memikirkan jangka panjang dalam melakukan pembelian. Pada rata-rata indeks pembelian impulsif generasi $Y$, ditemukan bahwa generasi ini memiliki nilai rataan yang cenderung lebih tinggi dibandingkan dengan generasi lainnya.

Berdasarkan uji anova ditemukan perbedaan yang signifikan antara generasi baby boomer dan generasi $Y$ pada dimensi cognitive, sedangkan pada dimensi affective tidak ada perbedaan di antara ketiga generasi. Pada variabel pembelian impulsif secara umum juga tidak ditemukan perbedaan yang signifikan antargenerasi (Tabel 4).

Cognitive. Generasi baby boomer adalah generasi yang paling sering untuk mempertimbangkan baik-baik sebelum membeli. Generasi $X$ dan generasi $Y$ mengaku bahwa pembelian yang dilakukan, sebelumnya sudah direncanakan. Generasi baby boomer, dibandingkan dengan generasi lainnya cenderung hanya membeli apa yang dibutuhkan saja. Hal ini dikarenakan secara cognitive generasi baby boomer dapat membedakan kebutuhan dan keinginan secara baik.

Affective. Generasi $Y$ mengaku bahwa sulit untuk menekan keinginan membeli suatu barang. Mayoritas generasi baby boomer tidak sulit untuk menekan keinginan membeli sesuatu. Generasi X mengaku jarang menyesal setelah melakukan pembelian. Responden generasi $Y$ seringkali langsung membeli jika melihat ada diskon.
Tabel 4 Sebaran responden dan rataan indeks berdasarkan kategori dimensi pembelian impulsif

\begin{tabular}{|c|c|c|c|c|}
\hline Kategori & $\begin{array}{l}\text { Gen } \\
\text { BB }\end{array}$ & $\begin{array}{c}\text { Gen } \\
X\end{array}$ & $\begin{array}{c}\text { Gen } \\
Y\end{array}$ & $\begin{array}{c}\text { Semua } \\
\text { Gen }\end{array}$ \\
\hline Cognitive & & & & \\
\hline Rendah & 100,0 & 90,0 & 90,0 & 93,3 \\
\hline Sedang & 0,0 & 10,0 & 10,0 & 6,7 \\
\hline Tinggi & 0,0 & 0,0 & 0,0 & 0,0 \\
\hline $\begin{array}{l}\text { Rataan } \\
\text { indeks }\end{array}$ & $25,7^{\mathrm{ab}}$ & $\begin{array}{r}29,1^{b} \\
a c\end{array}$ & $\begin{array}{r}34,7^{c} \\
b\end{array}$ & 29,8 \\
\hline$p$-value & \multicolumn{4}{|c|}{$0,078^{*}$} \\
\hline \multicolumn{5}{|l|}{ Affective } \\
\hline Rendah & 100,0 & 93,3 & 96,7 & 96,7 \\
\hline Sedang & 0,0 & 3,3 & 3,3 & 2,2 \\
\hline Tinggi & 0,0 & 3,3 & 0,0 & 1,1 \\
\hline $\begin{array}{l}\text { Rataan } \\
\text { indeks }\end{array}$ & 32,2 & 35,0 & 35,0 & 34,1 \\
\hline$p$-value & \multicolumn{4}{|c|}{0,729} \\
\hline \multicolumn{5}{|l|}{$\begin{array}{l}\text { Pembelian } \\
\text { Impulsif }\end{array}$} \\
\hline Rendah & 100,0 & 93,3 & 96,7 & 96,7 \\
\hline Sedang & 0,0 & 6,7 & 3,3 & 3,3 \\
\hline Tinggi & 0,0 & 0,0 & 0,0 & 0,0 \\
\hline $\begin{array}{l}\text { Rataan } \\
\text { indeks }\end{array}$ & 28,6 & 31,7 & 34,8 & 31,72 \\
\hline$p$-value & \multicolumn{4}{|c|}{0,193} \\
\hline
\end{tabular}

Keterangan: *)signifikan pada $p$ value $<0,1$, Huruf superscript yang berbeda menunjukkan adanya perbedaan signifikan antar generasi; ${ }^{a b}=$ Generasi baby boomer berbeda signifikan dengan generasi $Y$; ${ }^{\text {bac }}=$ Generasi $X$ tidak berbeda signifikan dengan generasi baby boomer, generasi $X$, dan generasi $Y$; ${ }^{c d}=$ Generasi $Y$ berbeda signifikan dengan generasi baby boomer

Pengaruh Nilai, Kontrol Diri, dan Sikap terhadap Pembelian Impulsif

Uji pengaruh menggunakan model Structual Equation Modelling (SEM) dengan aplikasi Smart PLS 3.0. Angka koefisien jalur menunjukkan pengaruh antar variabel, pada baris pertama menunjukkan koefisien jalur pada generasi baby boomer, baris kedua generasi $X$, baris ketiga generasi $\mathrm{Y}$, dan baris terakhir adalah koefisien jalur pada semua generasi (Gambar 3).

Penelitian ini memiliki 20 hipotesis yang akan dilihat pengaruhnya antara satu variabel dengan variabel lainnya menggunakan uji model SEM. Satu variabel dikatakan berpengaruh terhadap variabel lain jika memiliki nilai $t$-statistics $>1,96$ atau $p$ value $<0,05$. Nilai $t$ statistics diatas 1,96 dan $p$-value dibawah 0,05 menunjukkan adanya pengaruh yang signifikan antara dua variabel. 
Tabel 5 Hasil pengujian hipotesis model SEM

\begin{tabular}{|c|c|c|c|c|c|c|c|c|}
\hline \multirow{2}{*}{ Jalur } & \multicolumn{2}{|c|}{ Gen BB } & \multicolumn{2}{|c|}{ Gen X } & \multicolumn{2}{|c|}{ Gen Y } & \multicolumn{2}{|c|}{ Semua Gen } \\
\hline & $\mathrm{PC}$ & Ket & $\mathrm{PC}$ & Ket & $\mathrm{PC}$ & Ket & $\mathrm{PC}$ & Ket \\
\hline Nilai $\rightarrow$ sikap & 0,084 & $\begin{array}{l}\text { Tolak } \\
\text { H1a }\end{array}$ & 0,048 & $\begin{array}{l}\text { Tolak } \\
\text { H1b }\end{array}$ & 0,174 & $\begin{array}{l}\text { Tolak } \\
\text { H1c }\end{array}$ & $-0,059$ & $\begin{array}{l}\text { Tolak } \\
\text { H1d }\end{array}$ \\
\hline $\begin{array}{l}\text { Kontrol diri } \rightarrow \\
\text { sikap }\end{array}$ & 0,116 & $\begin{array}{l}\text { Tolak } \\
\text { H2a }\end{array}$ & $0,628^{*}$ & $\begin{array}{c}\text { Terima } \\
\mathrm{H} 2 \mathrm{~b}\end{array}$ & 0,263 & $\begin{array}{l}\text { Tolak } \\
\text { H2c }\end{array}$ & $0,367^{*}$ & $\begin{array}{c}\text { Terima } \\
\mathrm{H} 2 \mathrm{~d}\end{array}$ \\
\hline $\begin{array}{l}\text { Nilai } \rightarrow \text { pembelian } \\
\text { impulsif }\end{array}$ & 0,165 & $\begin{array}{l}\text { Tolak } \\
\text { H3a }\end{array}$ & 0,160 & $\begin{array}{l}\text { Tolak } \\
\text { H3b }\end{array}$ & $-0,069$ & $\begin{array}{l}\text { Tolak } \\
\text { H3c }\end{array}$ & 0,109 & $\begin{array}{l}\text { Tolak } \\
\text { H3d }\end{array}$ \\
\hline $\begin{array}{l}\text { Sikap } \rightarrow \text { pembelian } \\
\text { impulsif }\end{array}$ & 0,139 & $\begin{array}{l}\text { Tolak } \\
\mathrm{H} 4 \mathrm{a}\end{array}$ & 0,375 & $\begin{array}{l}\text { Tolak } \\
\text { H4b }\end{array}$ & $-0,538$ & $\begin{array}{l}\text { Tolak } \\
\text { H4c }\end{array}$ & 0,192 & $\begin{array}{l}\text { Tolak } \\
\text { H4d }\end{array}$ \\
\hline $\begin{array}{l}\text { Kontrol diri } \rightarrow \\
\text { pembelian impulsif }\end{array}$ & $-0,472^{\star \star *}$ & $\begin{array}{c}\text { Terima } \\
\text { H5a }\end{array}$ & $-0,457$ & $\begin{array}{l}\text { Tolak } \\
\text { H5b }\end{array}$ & 0,291 & $\begin{array}{l}\text { Tolak } \\
\text { H5c }\end{array}$ & $-0,336^{\star * *}$ & $\begin{array}{c}\text { Terima } \\
\text { H5d }\end{array}$ \\
\hline Adjusted $R$ square & \multicolumn{2}{|c|}{0,213} & \multicolumn{2}{|c|}{0,507} & \multicolumn{2}{|c|}{0,222} & \multicolumn{2}{|c|}{0,175} \\
\hline
\end{tabular}

Tanda negatif pada path coefficient menunjukkan adanya hubungan yang negatif di antara dua variabel. Nilai adjusted $\mathrm{R}$ square pada variabel pembelian impulsif generasi $X$ adalah yang terbesar, yakni 0,507 atau 50,7 persen variabel pembelian impulsif dijelaskan oleh variabel yang diteliti. Pada semua generasi, nilai adjusted $R$ square adalah yang terendah yakni 0,175 atau 82,5 persen variabel pembelian impulsif dijelaskan oleh variabel lain yang tidak diteliti seperti misalnya promosi dari perusahaan (Tabel 5).
Gambar 3 menggambarkan hasil uji menggunakan metode Structural Equation Modeling (SEM) dengan basis aplikasi Partial Least Square (PLS) pada variabel nilai terhadap variabel sikap menunjukkan hasil yang menolak $\mathrm{H} 1 \mathrm{a}, \mathrm{H} 1 \mathrm{~b}, \mathrm{H} 1 \mathrm{c}$, dan $\mathrm{H} 1 \mathrm{~d}$. Hal ini terlihat dari hasil $t$-statistics yang nilainya dibawah 1,96, baik pada uji generasi baby boomer, generasi $\mathrm{X}$, generasi $\mathrm{Y}$, atau gabungan dari ketiganya.

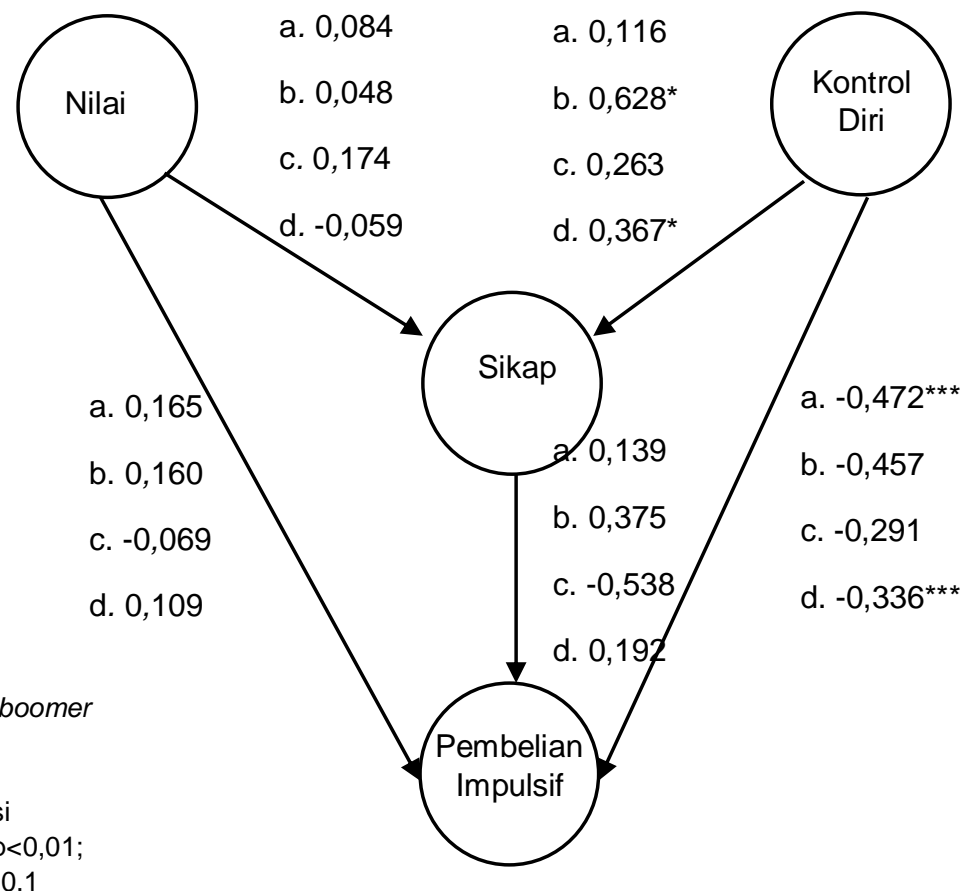

Keterangan:

- a: Generasi baby boome

- b: Generasi X

- c: Generasi Y

- d: Semua generasi

${ }^{* * *}$ Signifikan pada $p<0,01$;

*Signifikan pada $p<0,1$ 
Berdasarkan hasil uji $\mathrm{H} 2 \mathrm{~b}$ dan $\mathrm{H} 2 \mathrm{~d}$ pada responden generasi $X$ dan responden semua generasi, menunjukkan hasil yang mendukung hipotesis bahwa kontrol diri berpengaruh positif dan signifikan terhadap sikap. Hal ini berarti bahwa semakin tinggi kontrol diri akan mendorong terbentuknya sikap yang positif pada individu begitu pula sebaliknya. Dugaan pada $\mathrm{H} 2 \mathrm{a}$ dan $\mathrm{H} 2 \mathrm{~d}$ bahwa kontrol diri dapat berpengaruh terhadap sikap pada generasi $X$ dan semua generasi sejalan dengan temuan pada penelitian ini. Hal berbeda ditemukan pada generasi baby boomer dan generasi $\mathrm{Y}$, yakni kontrol diri tidak memengaruhi sikap.

Pada H3a, H3b, H3c, dan H3d hipotesis ditemukan tidak sejalan dengan hasil uji pengaruh. Berdasarkan hasil uji pada penelitian ini dikatakan bahwa nilai pada responden generasi baby boomer, generasi $\mathrm{X}$, generasi $\mathrm{Y}$, dan gabungan dari ketiganya tidak berpengaruh signifikan terhadap pembelian impulsif. Hasil serupa juga ditemukan pada $\mathrm{H} 4 \mathrm{a}, \mathrm{H} 4 \mathrm{~b}, \mathrm{H} 4 \mathrm{c}$, dan $\mathrm{H} 4 \mathrm{~d}$, yang berarti bahwa sikap tidak signifikan memengaruhi pembelian impulsif.

Berdasarkan uji $\mathrm{H} 5 \mathrm{a}$ dan $\mathrm{H} 5 \mathrm{~d}$, pada responden generasi baby boomer dan responden semua generasi ditemukan bahwa kontrol diri berhubungan negatif. Pada uji ini juga ditemukan berpengaruh signifikan terhadap pembelian impulsif. Hal yang berbeda terlihat pada hasil uji pada generasi $X$ dan generasi $Y$ yang ditemukan bahwa kontrol diri tidak berpengaruh signifikan terhadap pembelian impulsif.

\section{PEMBAHASAN}

Hasil penelitian ini menemukan bahwa pada variabel nilai menurut generasi baby boomer, generasi $X$, dan generasi $Y$; hubungan dalam keluarga merupakan hubungan yang paling penting dan kebutuhan keluarga jauh lebih penting daripada kebutuhan pribadi. Selain itu, bagi ketiga generasi tersebut menjaga hubungan dengan tetangga juga merupakan suatu hal yang penting. Bahkan, berdasarkan keterangan dari beberapa responden generasi baby boomer kehidupan bertetangga menjadi penting untuk mengobati rasa kesepian ketika berada di rumah. Hal-hal yang sering dilakukan oleh generasi baby boomer bersama tetangga dan kelompok sosialnya di antaranya adalah arisan dan pengajian. Berdasarkan temuan pada penelitian ini generasi baby boomer cenderung lebih berani mengambil risiko dan mudah dalam mengambil keputusan dibandingkan dengan dua generasi lainnya. Hal ini sejalan dengan penelitian kerjasama dari Kementerian Perlindungan Perempuan dan Anak dan Badan Pusat Statistik (KEMEN PPPA \& BPS, 2018) yang menyatakan bahwa generasi baby boomer lebih teguh dalam memegang prinsip dan lebih konservatif sehingga berani mengambil keputusan. Generasi baby boomer berdasarkan penelitian Parment (2013) juga tidak terlalu khawatir tanggapan orang lain atas produk yang dibelinya.

Berdasarkan temuan pada variabel kontrol diri, generasi $Y$ cenderung lebih mudah berubah pikiran dibandingkan dengan kedua generasi lainnya. Hal ini dikarenakan generasi $Y$ cenderung suka untuk mencoba hal-hal baru dan melihat-lihat produk yang baru. Parment (2013) menyatakan bahwa generasi $Y$ suka untuk melihat produk baru di sebuah toko tanpa adanya kebutuhan ataupun keinginan untuk membeli. Pada penelitian ini juga ditemukan bahwa generasi $X$ cenderung lebih suka untuk menunda pekerjaan. Responden generasi ini persentase terbesarnya adalah ibu rumah tangga penuh waktu, hal ini menjadikan responden lebih memiliki waktu yang leluasa dan fleksibel untuk melakukan pekerjaannya ataupun menunda untuk mengerjakannya. Hal berbeda justru ditunjukkan oleh generasi baby boomer yang cenderung lebih mampu bersikap disiplin, Meskipun telah pensiun dan berada pada masa retirement, jiwa workaholic yang dimiliki generasi baby boomer menurut Hawkins, Mothersbaugh, dan Best (2010) masih melekat sehingga mendorong perilaku disiplin.

Generasi $Y$ pada variabel sikap ditemukan cenderung dipengaruhi mood yang sedang dirasakan ketika melakukan pembelian. Hal ini menjadi temuan yang penting karena menurut Solomon (2017) model terbaru yang mengukur sikap terhadap perilaku pembelian juga berfokus pada bagaimana perasaan seseorang tentang membeli atau menggunakan suatu produk. Generasi Y pada penelitian ini juga ditemukan cenderung senang membeli produk yang juga dibeli orang lain, atau dengan kata lain keputusan pembeliannya dipengaruhi oleh lingkungan sosialnya. Hal ini sejalan dengan temuan Parment (2013) yang mengatakan bahwa generasi $Y$ lebih dipengaruhi lingkungan sosialnya dalam melakukan pembelian dibandingkan dengan generasi baby boomer.

Generasi Baby Boomer memiliki perilaku pembelian impulsif yang terendah dibandingkan dengan dua generasi lainnya. Generasi baby 
boomer, generasi $\mathrm{X}$, dan generasi $\mathrm{Y}$ mengaku tidak mudah percaya pada iklan di media massa. Berdasarkan wawancara, sumber informasi yang paling dipercaya dari generasi baby boomer dan generasi $\mathrm{X}$ adalah dari toko langsung, sedangkan internet menjadi sumber informasi terpercaya bagi generasi $Y$. Berdasarkan data dari Kementerian Perlindungan Perempuan dan Anak dan Badan Pusat Statistik (KEMEN PPPA \& BPS, 2018), sebesar 56,42 persen generasi $Y$ Indonesia telah menggunakan internet dan kebanyakan berada di wilayah perkotaan. Hal ini sejalan dengan lokasi pengambilan data yang juga berada di wilayah perkotaan, yakni di Kota Surabaya.

Pada variabel pembelian impulsif, generasi baby boomer dibandingkan dengan dua generasi lainnya cenderung lebih mempertimbangkan baik-baik sebelum membeli dan hanya membeli apa yang dibutuhkan saja. Hal ini sejalan dengan temuan dalam wawancara mendalam bahwa generasi baby boomer sering membuat perencanaan pembelian untuk membeli kebutuhannya. Generasi $Y$ ditemukan cenderung langsung membeli produk ketika terdapat diskon, bahkan ketika produk tersebut bukan sebuah kebutuhan.

Berdasarkan penelitian dari Karbasivar dan Yarahmadi (2011) promosi dari perusahaan baik dalam bentuk diskon maupun bentuk lainya dapat mendorong pembelian impulsif konsumen. Generasi X cenderung merasa lebih sulit untuk tidak membeli produk yang terlihat bagus di toko. Sebuah produk dapat terlihat menarik dipengaruhi oleh keadaan tokonya atau biasa disebut dengan store environment dan tata letak produk yang ditampilkan atau window displays. Menurut Vishnu dan Raheem (2013) store environment dan window displays adalah faktor signifikan yang memengaruhi pembelian impulsif. Selain itu, store image dan emosi adalah faktor lain yang memengaruhi seorang konsumen untuk berbelanja ulang (Simanjuntak, Nur, Sartono, \& Sabri, 2020).

Selanjutnya, penelitian ini juga ingin menganalisis perbedaan antargenerasi pada variabel penelitan. Hasil menunjukkan bahwa generasi baby boomer dan generasi $Y$ merupakan generasi yang memiliki family values tinggi. Hal ini sejalan dengan penelitian dari Williams dan Page (2011) yang mengatakan bahwa tanggung jawab keluarga bagi generasi baby boomer itu penting. Pada uji beda dengan one way anova ini ditemukan bahwa tidak terdapat perbedaan yang signifikan di antara generasi baby boomer, $\mathrm{X}$, dan $\mathrm{Y}$ pada dimensi variabel nilai. Hal ini sejalan dengan penelitian Eibel dan Hofmeister (2013) yang menyatakan bahwa nilai keluarga adalah salah satu nilai yang dapat melewati batas-batas geografis dan bersifat universal.

Generasi baby boomer memiliki kontrol diri yang tinggi dibandingkan dengan generasi $X$ dan $Y$. Hal ini sejalan dengan penelitian dari Ghufron dan Risnawati (2010) yang mengatakan bahwa semakin tua seseorang, maka semakin baik kontrol dirinya. Hal ini sejalan juga dengan temuan saat wawancara mendalam, bahwa setengah dari responden generasi baby boomer dalam melakukan keputusan pembelian memiliki kontrol atas dirinya sendiri dan tidak bergantung dan terpengaruh orang lain. Variabel kontrol diri dalam uji menggunakan one way anova ditemukan perbedaan yang signifikan pada dimensi inhibitory antara generasi baby boomer dengan generasi $\mathrm{X}$ dan $\mathrm{Y}$.

Sikap dalam penelitian ini dikategorikan menjadi tiga, yakni negatif, netral, dan positif (Marlius, 2017). Pada penelitian ini, generasi baby boomer, generasi $\mathrm{X}$, generasi $\mathrm{Y}$, dan semua generasi memiliki sikap yang terkategori netral. Pada dimensi affective, generasi baby boomer, generasi $X$, dan generasi $Y$ persentase terbesarnya dalam kategori negatif, hal ini menunjukkan bahwa responden cenderung tidak mengedepankan perasaan dalam mengambil sikap pembelian, sedangkan pada dimensi behavior rata-rata tergolong netral. Pada uji beda ditemukan perbedaan yang signifikan pada dimensi cognitive., Dimensi cognitive menjelaskan mengenai standar pengetahuan yang dimiliki responden sebagai konsumen (Simamora, 2002). Jika pengetahuan dikaitkan dengan lama pendidikan yang ditempuh responden, maka hal ini sejalan dengan karakteristik responden pada penelitian ini, bahwa generasi baby boomer memiliki lama pendidikan yang terendah dan generasi $Y$ yang tertinggi. Hal ini dapat menyebabkan dimensi cognitive pada generasi baby boomer berbeda signifikan dengan generasi $\mathrm{X}$ dan $\mathrm{Y}$.

Pada penelitian ini ditemukan bahwa semua responden generasi baby boomer tergolong rendah pembelian impulsifnya. Hal ini sejalan dengan penelitan Sapitri dan Suprapti (2014) yang mengatakan bahwa semakin tua usia konsumen, maka semakin rendah pembelian impulsifnya. Pada rataan indeks pembelian impulsif generasi $Y$, ditemukan bahwa generasi ini memiliki nilai rataan yang cenderung lebih tinggi dibandingkan dengan generasi lainnya. 
Dapat dikatakan bahwa generasi $Y$ lebih impulsif, hal ini sejalan dengan penelitian Zhang, Winterich, dan Mittal (2010) yang menemukan bahwa, konsumen wanita yang memiliki uang lebih banyak, cenderung memiliki pembelian impulsif yang tinggi. Berdasarkan karakteristik pendapatan pada penelitian ini, generasi $Y$ memiliki pendapatan per kapita yang tertinggi dibandingkan dengan generasi lainnya. Wells, Farley, dan Armstrong (2007) menyatakan bahwa tingkat pendapatan berpengaruh positif pada pembelian impulsif pada konsumen.

Hasil uji pengaruh pada variabel nilai ditemukan tidak berpengaruh terhadap variabel sikap maupun terhadap pembelian impulsif pada generasi baby boomer, generasi $\mathrm{X}$, generasi $\mathrm{Y}$, dan semua generasi. Hal ini ditunjang dengan penelitian dari Solomon (2017) yang menyatakan bahwa nilai tidak dapat membantu untuk menjelaskan perilaku konsumen, hal ini disebabkan karena konsep nilai yang luas. Gültekin dan Özer (2012) juga mengatakan bahwa nilai tidak memengaruhi pembelian impulsif. Selain itu, nilai juga bersifat normatif sehingga tidak mampu mendorong sikap pada individu.

Berdasarkan wawancara mendalam ditemukan bahwa yang dapat mendorong perilaku pembelian responden adalah sosok yang ada dalam keluarga atau lingkungannya seperti suami, anak, cucu, ataupun teman, bukan pada nilai keluarga atau nilai komunitas, Hal ini sejalan dengan indikator yang terdapat dalam variabel nilai bahwa responden lebih mementingkan kebutuhan keluarga daripada kebutuhannya sendiri. Penelitian ini sejalan dengan penelitian Ruwani, Retnaningih, dan Simanjuntak (2014) serta Hartatin dan Simanjuntak (2016) yang menemukan bahwa nilai tidak berpengaruh terhadap perilaku pembelian. Namun dengan demikian, hal ini bertentangan dengan penelitian dari Paasovaara (2011) dan Sumarwan (2011) yang mengatakan bahwa nilai menentukan sikap konsumen.

Hasil uji pengaruh menunjukkan bahwa kontrol diri berpengaruh positif dan signifikan terhadap sikap. Hal ini berarti bahwa semakin tinggi kontrol diri akan mendorong terbentuknya sikap yang positif pada individu begitu pula sebaliknya, semakin rendah kontrol diri pada individu akan juga mendorong sikap yang negatif. Hasil ini sesuai dengan penemuan dari Giner (2001) yang menyatakan bahwa kontrol diri dapat mendorong kesadaran yang positif pada individu sebelum mengambil sikap. Faber dan Vohs (2004) juga menyatakan bahwa semakin berkurangnya tingkat kontrol atas diri sendiri pada konsumen akan memengaruhi sikap konsumen dalam pengambilan keputusan pembelian. Fudenberg dan Levine (2012) juga menyatakan bahwa kontrol diri dapat menjelaskan heterogenitas sikap antar individu.

Secara umum, pembelian impulsif dikaitkan dengan kemampuan kontrol diri seseorang atas perilaku pembeliannya (Dholakia, Gopinath, Bagozzi, dan Nataraajan, 2006; Fujita, Trope, Liberman, Levin, dan Sagi, 2006; Vohs \& Faber, 2007). Kontrol diri dalam uji pnegaruh ditemukan berhubungan negatif dan berpengaruh signifikan terhadap pembelian impulsif. Hal ini sejalan dengan temuan dari Larasati dan Budiani (2014) yang menyatakan bahwa semakin tinggi kontrol diri, maka semakin rendah pembelian impulsif pada konsumen, begitu juga sebaliknya semakin rendah kontrol diri maka semakin tinggi pembelian impulsifnya.

Lebih lanjut, Sultan, Joireman, dan Sprott (2012) juga mengatakan bahwa pembelian impulsif dapat dikurangi dengan melakukan latihan kontrol diri secara konsisten. Roberts dan Chris (2012), juga mengatakan bahwa kontrol diri berpengaruh terhadap pembelian impulsif. Hal yang berbeda terlihat pada generasi $X$ dan generasi $\mathrm{Y}$, ditemukan bahwa kontrol diri tidak berpengaruh signifikan terhadap pembelian impulsif. Namun, pada wawancara mendalam ditemukan bahwa kedua generasi ini cenderung tidak memiliki kontrol diri yang baik berkaitan dengan kebutuhan fashion seperti baju, sepatu, tas, dan lain sebagainya sehingga seringkali membelinya tanpa perencanaan.

Variabel sikap dalam uji pengaruh ini tidak ditemukan pengaruhnya terhadap pembelian impulsif, baik pada generasi baby boomer, generasi $X$, generasi $Y$, maupun semua generasi. Temuan ini sejalan dengan penelitian Zikri, Yuliati, dan Simanjuntak (2019) yang menyatakan bahwa sikap tidak berpengaruh nyata terhadap perilaku konsumen. Hal ini bertolak belakang dengan temuan Hetharie (2012) bahwa sikap positif konsumen saat berbelanja dapat memengaruhi pembelian impulsif. Menurut Solomon (2017) dalam beberapa kasus, sikap seorang individu tidak dapat memprediksi perilakunya. Pada penelitian ini, ditemukan bahwa kategori sikap pada responden adalah netral sehingga tidak ada kecenderungan pada sikap tertentu seperti sikap yang positif (melakukan) atau negatif (tidak melakukan). 


\section{SIMPULAN DAN SARAN}

Variabel nilai, kontrol diri, dan sikap mayoritas responden pada generasi baby boomer, X, Y, dan gabungan dari ketiganya masuk dalam kategori rendah dan sedang, Namun, dalam uji beda variabel lintas generasi, ditemukan bahwa pada variabel kontrol diri, sikap, dan pembelian impulsif terdapat perbedaan yang signifikan antargenerasi. Hasil penelitian menemukan bahwa hanya pada variabel nilai yang tidak berbeda signifikan. Pada variabel sikap, generasi $X$ tidak berbeda signifikan dengan generasi $Y$. Pada uji pengaruh variabel nilai dalam penelitian ini ditemukan tidak berpengaruh terhadap sikap dan pembelian impulsif baik pada generasi baby boomer, X, Y, maupun gabungan dari ketiganya. Pada variabel kontrol diri, ditemukan memengaruhi sikap dan pembelian impulsif. Kontrol diri memengaruhi sikap ditemukan pada responden generasi $X$ dan gabungan dari tiga generasi, sedangkan kontrol diri yang memengaruhi pembelian impulsif ditemukan pada responden generasi baby boomer dan gabungan dari ketiga generasi. Kontrol diri ditemukan berhubungan negatif dan berpengaruh signifikan terhadap pembelian impulsif. Pada variabel sikap, dalam penelitian ini tidak ditemukan pengaruhnya terhadap pembelian impulsif.

Saran pada penelitian selanjutnya dapat menggunakan variabel promosi, store environment, dan window display untuk melihat pengaruhnya terhadap pembelian impulsif. Selain itu, agar lebih dapat terlihat bagaimana perbedaan perilaku konsumen berdasarkan gendernya dalam setiap generasi dapat ditambahkan cakupan respondennya tidak hanya perempuan. Pada bagian karakteristik juga dapat dikurangi kategorinya disesuaikan dengan kebutuhan penelitian agar lebih spesifik dalam penyajian data. Berdasarkan hasil penelitian ini, ditemukan bahwa ibu rumah tangga lintas generasi memiliki tingkat pembelian impulsif yang rendah. Akan tetapi harus diwaspadai, karena saat ini banyak perusahaan telah menggunakan banyak strategi untuk mendapatkan segmentasi pemasaran yang luas sehingga dapat mendorong konsumen untuk melakukan pembelian impulsif, terutama dengan iklan, promosi, maupun diskon besar-besaran. Salah satu cara untuk mencegah pembelian impulsif adalah dengan membiasakan diri untuk mencatat daftar barang yang dibeli, skala prioritas, dan membuat catatan pemasukan serta pengeluaran rumah tangga. Selain itu, anak-anak atau cucu juga menjadi pendorong bagi generasi baby boomer, $\mathrm{X}$, maupun $\mathrm{Y}$ untuk melakukan pembelian impulsif. Disarankan agar memberikan pendidikan finansial sejak dini pada anak. Seperti misalnya, mengajarkan anak untuk menabung jika ingin membeli barang yang diinginkan. Bagi praktisi dan pembuat kebijakan pada bidang konsumen dapat memberikan edukasi yang lebih mengenai manajemen keuangan dan kebutuhan untuk menghindari perilaku pembelian impulsif yang merugikan konsumen. Selain itu juga dapat mendorong produsen untuk melakukan pemasaran secara lebih bijak.

\section{DAFTAR PUSTAKA}

[BPS] Badan Pusat Statistik. (2018). Statistik Indonesia Tahun 2018. Jakarta Pusat, ID: BPS.

[KEMEN PPPA \& BPS] Kementerian Perlindungan Perempuan dan Anak \& Badan Pusat Statistik. (2018). Profil Generasi Milenial Indonesia. Jakarta, ID: Kementerian Perlindungan Perempuan dan Anak.

Belch, G., \& Belch, M. (2004). Advertising and promotion (6th Ed). New York, US: Mc. Graw-Hill.

Burrough, J, E., \& Rindfleisch, A. (2002). Materialism and well-being: A confticting values perspective. Journal of Consumer Research, 29(3), 348-370. doi:10,1086/344429

Codrington, G. (2008). Detailed introduction to generational theory. Tomorrow Today, 116.

Dholakia, U., Gopinath, M., Bagozzi, R., \& Nataraajan, R. (2006). The role of regulatory focus in the experience and self-control of desire for temptations. Journal of Consumer Psychology, 16(2), 165-177.

Dickey, J., \& Sullivan, J. (2007). Generational shift in media habits. Media Week, 17(7), 10.

Donnelly, A. (2008). Playing to the digital generation. Marketing, 16(April), 19-20.

Eibel, S. K., \& Hofmeister, T. A. (2013). The impact of values on consumer behaviour. International Journal of Economics and Business Research, 5(4), 400-419.

Ezell, B. (2009). Banking on the next generations. Michigan Banker, 21(19), 2729.

Faber, R. J., \& Vohs, K. D. (2004). To buy or not to buy? Self-control and self-regulatory 
failure in purchase behavior. In RF Baumeister dan KD. Vohs (Eds.). Handbook of self-regulation: research, theory, and applications. New York, US: Guilford Press.

Fudenberg, D., \& Levine, D, K. (2012). Timing and self-control. Econometrica, 80(1), 142. doi:10,3982/ECTA9655.

Fujita, K., Trope, Y., Liberman, N., \& LevinSagi, M. (2006). Construal levels and self-control. Journal of Personality and Social Psychology, 90(3), 351-367.

Gania, R. R., \& Simanjuntak, M. (2019). Lifestyle, self-esteem, money attitude and compulsive buying between generations. Bogor, ID: ISFCl (International Seminar on Family and Consumer Issues)

Ghufron, N., \& Risnawati, R. (2010). Teori-teori psikologi. Jogjakarta, ID: Ar-Ruz Media Group.

Giner, S, R. (2001). Guilty pleasures and grim necessities: Affective attitudes in dilemmas of self-control. Journal of Personality and Social Psychology, 80(2), 206.

Gültekin, B., \& Özer, L. (2012). The influence of hedonic motives and browsing on impulse buying. Journal of Economics and Behavioral Studies, 4(3), 180-189.

Gunawan, S. (2015). The impact of motivation, perception and attitude toward consumer purchasingdecision: A study case of Surabaya and Jakarta society on carl's junior. iBuss Management, 3(2), 154-163.

Hartatin, D., \& Simanjuntak, M. (2016). The effect of value and reference group on young consumer's hedonic buying. Journal of Consumer Sciences, 1(1), 33-46. doi:https://doi.org/10.29244/jcs.1.1.33-46

Hawkins, D, I., Mothersbaugh, D, L., \& Best, R, J. (2010). Consumer behavior (11th Ed). New York, US: Mc. Graw-Hill.

Herabadi, A, G. (2003). Buying impulses: A study on impulsive consumption (Dissertation). Nijmegen, NL: Radboud University Nijmegen.

Hetharie, J. A. (2012). Model kecenderungan pembelian impulsive: Studi pada konsumen matahari departement store Kota Ambon. Jurnal Manajemen Teknologi, 11(3), 280-294.

Hurlock, E. B. (2006). Adolence developmment (4th Ed). Tokyo, JP: MC GrawHill Kogokusha Ltd.

Karbasivar, A, \& Yarahmadi H. (2011). Evaluating effective factors on consumer impulse buying behaviour. Asian Journal of Business Management Studies, 2(4), 174181.

Kotler, P., \& Armstrong. (2008). Prinsip-prinsip pemasaran (Ed 12). Jakarta, ID: Airlangga.

Kusmarini, R. A., Sumarwan, U., \& Simanjuntak, M. (2020). The effect of atmosphere perception, perceived value, and hedonic value on consumer loyalty through the service quality of warunk upnormal. Indonesian Journal of Business and Entrepreneurship (IJBE), 6(1), 53-65. doi:https://doi.org/10.17358/ijbe.6.1.53

Larasati, M, A., \& Budiani, M, S. (2014). Hubungan antara kontrol diri dengan pembelian impulsif pakaian pada mahasiswi psikologi Universitas Negeri Surabaya yang melakukan pembelian secara online. Character: Jurnal Penelitian Psikologi, 2(3).

Laroche, M., Pons, F., Zgolli, N., Cervellon, M. C., \& Kim, C. (2003). A model of consumerresponse to two retail sales promotion techniques. Journal of Business Research, 56, 513-522.

Livadas, S. (2009). Communities prepare to meet need of baby boomers. Rochester Business Journal, 25(13), 20.

Marlius, D. (2017). Keputusan pembelian berdasarkan faktor psikologis dan bauran pemasaran pada PT. Intercom Mobilindo Padang. Jurnal Pundi, 1(1), 56-66.

Paasovaara, R. (2011). Consumers' food product experience. Acta Wasaensia, 176.

Parment, A. (2013). Generation $Y$ vs. baby boomers: Shopping behavior, buyer involvement and implications for retailing. Journal of Retailing and Consumer Services, 20(2), 189-199.

Pramesty, D. W., \& Simanjuntak, M. (2020). Konsep diri, gaya hidup, strategi pemasaran, dan pembelian impulsif antargenerasi. Jurnal IImu Keluarga \& Konsumen, 13(1), 87-98. doi:https://doi.org /10.24156/jikk.2020.13.1.87

Putri, P. T., \& Simanjuntak, M. (2020). The role of motivation, locus of control and financial literacy on women investment decisions across generations. Journal of Consumer Sciences, 5(2), 102-123. doi:https://doi.org /10.29244/jcs.5.2.102-123

Read, E. (2007). Y and baby boomers. New Zealand Management, 63. 
Roberts, J. A. \& Chris, M. (2012). Cooking up a recipe for self control: The three ingredients of self control and its impact on impulse buying. Journal of Theory And Practice, 20(2), 173-188.

Rosenberg, J. (2008). Mind your generation. Journal of Property Management, 73(6), 41-44.

Ruwani, A., Retnaningsih., \& Simanjuntak, M. (2014). Nilai dan tipe konsumen rumah tangga dan kaitannya dengan perilaku pembelian produk makanan kemasan. Jurnal IImu Keluarga \& Konsumen, 7(1), 48-57. doi:http://journal.IPB.ac.id /index.php/jikk/article/view/9996/7816

Sapitri, N. L. G. A., \& Suprapti, N. W. S. (2014). Hubungan variabel demografi dengan perilaku pembelian impulsif yang dimoderasi kepemilikan kartu kredit di Kota Denpasar. E-Journal Manajemen Universitas Udayana, 3(10), 3117-3133.

Simamora, H. (2002). Sumber daya manusia. Yogyakarta, ID: STIE YKPN.

Simanjuntak, M., \& Musyifah, I. (2016). Online shopping behavior on Generation $Y$ in Indonesia. Global Business Finance Review, 21(1), 33-45.

Simanjuntak, M., Nur, H.R., Sartono, B., \& Sabri, M.F. (2020). A general structural equation model of the emotions and repurchase intention in modern retail. Management Science Letters, 10(4), 801814. doi:10.5267/j.msl.2019.10.017

Solomon, M. R. (2017). Consumer behavior: Buying, having, and being (Ed 12th). Edinburgh, UK: Pearson Education Limited.

Sultan, A, J., Joireman, J., \& Sprott, D, E. (2012). Building consumer self-control: The effect of self control exercises on impulse buying urges. Marketing Letters, 23(1), 61-72.

Sumarwan, U. (2011). Perilaku konsumen: Teori dan penerapannya dalam pemasaran. Bogor, ID: Ghalia Indonesia.

Tangney, J., P., Boone, A., L,, \& Baumeister, R., F. (2018). High self-control predicts good adjustment, less pathology, better grades, and interpersonal success. In SelfRegulation and Self-Control, 72(2), 181220.
Unal, S., \& Ercis, A. (2006). Segmenting the market according to consumer decision making styles and personal value. Marmara Üniversitesi IiBF Dergisi, 21(1), 359-382.

Verplanken, B., \& Herabadi, A. (2001). Individual differences in impulsive buying tendency: Feeling and no thinking. European Journal of Personalit, 15, 71-83.

Vishnu, P., \& Raheem, A, R. (2013). Factors influencing impulse buying behavior. European Journal of Scientific Research, 100(3), 67-79.

Vohs, K. D., \& Faber, R. J. (2007). Spent resources: Self-regulatory resource availability affects impulse buying. Journal of Consumer Research, 33(3), 537-548.

Wells, L. E., Farley, H., \& Armstrong, G. A. (2007). The importance of packaging design for own-label food brands. International Journal of Retail and Distribution Management, 35(9), 677-690.

Williams, K, C., \& Page, R, A. (2011). Marketing to the generations. Journal of Behavioral Studies in Business, 3(1), 37-53.

Yilmaz, K, Gungordu, A., \& Yumusak, T. (2016). The relationship between the list of values and consumer decision making styles in the context of clothing products. Business Management Dynamics, 5(9), 1-14.

Yistiani, N. N. M., Yasa, N. N. K., \& Suasana, I. G. K. G. (2012). Pengaruh atmosfer gerai dan pelayanan ritel terhadap nilai hedonik dan pembelian impulsif pelanggan matahari department store duta plaza di Denpasar. Matrik: Jurnal Manajemen, Strategi Bisnis dan Kewirausahaan, 6(2), 139-149.

Zhang, Y., Winterich, K. P., \& Mittal, V. (2010). Power distance belief and impulsive buying. Journal of Marketing Research, 47(5), 945-954.

Zikri, Z., Yuliati, L. N., \& Simanjuntak, M. (2019). Pengaruh agen sosialisasi dan iklan TV terhadap sikap dan perilaku menyikat gigi pada siswa sekolah dasar. Jurnal Ilmu Keluarga \& Konsumen. 12(2), 169-180. https://doi.org/10.24156 /jikk.2019.12.2.169 